\title{
Epidemiological and environmental aspects of visceral leishmaniasis in children under 15 years of age between 2007 and 2012 in the City of Araguaína, State of Tocantins, Brazil
}

\author{
Iara Brito Bucar Oliveira ${ }^{[1]}$, Hebert Lima Batista ${ }^{[2]}$, Joênes Mucci Peluzio ${ }^{[3]}$, \\ Irmtraut Araci Hoffmann Pfrimer ${ }^{[4]}$, Flávia Melo Rodrigues ${ }^{[4]}$ \\ and José Rodrigues do Carmo Filho ${ }^{[4]}$
}

[1]. Faculdade de Ciências Humanas, Econômicas e da Saúde de Araguaína, Instituto Tocantinense Presidente Antônio Carlos, Araguaína, TO. [2]. Departamento de Medicina, Instituto Federal de Educação Ciências e Tecnologia do Tocantins, Araguaína, TO. [3]. Departamento de farmácia, Universidade Federal do Tocantins, Gurupi, TO. [4]. Programa de Pós-Graduação Stricto Sensu em Ciências Ambientais e Saúde, Pontifícia Universidade Católica de Goiás, Goiânia, GO.

\begin{abstract}
Introduction: Visceral leishmaniasis (VL) stands out as a zoonosis observed on four continents and also in urban expansion zones in several regions of Brazil. Methods: A cross-sectional epidemiological study of VL cases in children under 15 years of age in the period from 2007 to 2012. Clinical data were gathered from medical reports; meteorological data were obtained at the Meteorological Measurement Department of UFT. Environmental variables were divided into two periods, rainy and dry. Results: The study revealed no difference by gender $(\mathrm{p}=0.67)$ among the 821 patients. However, the most affected age group was between one and five years of age $(58.6 \%$; $<<0.01)$; the highest prevalence of the disease $(99.03 \%$; $<<0.01)$ occurred in urban zones; and the most affected ethnic group $(85.5 \%$; $<0.01)$ was mixed race. The highest incidence coefficients in this population occurred in 2007 and 2008 (578.39/100,000 inhabitants; 18.5/100,000 inhabitants, respectively), whereas the highest lethality coefficients occurred in 2008 and 2011 (0.85/100 deaths). There was no significant correlation between average rainfall and the number of VL cases. The correlation between temperature and number of VL cases was negative $(r=-0.4039 ; \mathrm{p}<0.01)$. Conclusions: In Araguaína, visceral leishmaniasis in children under 15 years is an urban-based endemic disease distributed across all districts of the city wherein temperature as an environmental factor, a higher prevalence in mixed race children between one and five years of age, and a high incidence coefficient all strongly contribute to child mortality.
\end{abstract}

Keywords: Visceral leishmaniasis. Epidemiology. Environmental factors.

\section{INTRODUCTION}

Visceral leishmaniasis (VL) stands out as a chronic disease with high incidence in tropical and subtropical areas of the world. Five hundred thousand new cases and 50,000 deaths are recorded annually ${ }^{1,2}$.

In Brazil, VL is deemed a rural disease; nonetheless, it currently displays urban characteristics. Reports show the emergence of nearly 3,000 new cases annually, and average mortality rates vary between $8 \%$ and $10 \%{ }^{3}$. This disease affects people in all age groups; however, it can be observed most noticeably in children 10 years of age or under ${ }^{4,5}$. In this age group, children are more exposed to contact with animals while still presenting nutritional deficits and a premature

Address to: Dr ${ }^{\text {a }}$ Iara Brito Bucar Oliveira. Avenida C, Quadra D, Lote 30, Jardim Santa Monica, 77809-600 Araguaína, TO, Brasil.

Phone: 5563 3411-1683; Mobile Number: 5563 9981-8897

e-mail: iarabucar@hotmail.com

Received 5 May 2014

Accepted 18 August 2014 immunological status ${ }^{6}$, which increases their risk of contracting the disease by 109.77 times when compared with older individuals.

The City of Araguaína, State of Tocantins, Brazil, is notable among the nation's municipalities for its high incidence of VL and is considered a VL-high-transmission municipality?

This study aimed to describe the environmental and epidemiological characteristics of VL in children under 15 years of age in the municipality of Araguaína, State of Tocantins.

\section{METHODS}

\section{Type of study}

The present research involves an analytical cross-sectional epidemiological study of VL cases diagnosed in the Hospital for Tropical Diseases and recorded in Araguaína between 2007 and 2011.

\section{Territory of the study}

Araguaína is located in the northern region of the State of Tocantins $\left(07^{\circ} 11^{\prime} 28^{\prime \prime S}\right.$ and $\left.48^{\circ} 12^{\prime} 26^{\prime \prime} \mathrm{W}\right)$ at an altitude of $227 \mathrm{~m}$. The area of the city is $4,000.416 \mathrm{~km}^{2}$, and the 
population is 164,093 . The city enjoys humid tropical weather and has two quite distinct seasons, a rainy season (from November through May) and a dry season (from June through October), with annual rainfall of $1,750 \mathrm{~mm}^{3}$ and temperatures varying between $20^{\circ} \mathrm{C}$ and $32^{\circ} \mathrm{C}^{10}$.

\section{Data collection}

Data were collected directly from medical reports on patients diagnosed with VL in the Hospital for Tropical Diseases in Araguaína, TO. Information on the average annual rainfall in millimeters, as well average annual temperature in degrees Celsius, was provided by the Meteorological Measurement Department of the Federal University of Tocantins - Veterinary Medicine Campus of Araguaína.

\section{Epidemiological analysis}

The incidence coefficient was calculated as the number of VL cases diagnosed in patients between 0 and 15 years of age divided by the population exposed to the disease in the same age group $\mathrm{x}$ 100,000 inhabitants.

The mortality coefficient was calculated as the number of deaths from VL occurring in patients 0 and 15 years of age divided by the total population in that age group $\mathrm{x} 100,000$ inhabitants.

The VL lethality coefficient, expressed as a percentage, results from a correlation between the number of deaths associated with a given cause and the number of people who were actually affected by the disease.

To establish the spatial distribution of the VL cases, they were grouped by primary healthcare unit (PHU).

\section{Statistical analysis}

The chi-squared test was employed for the analysis of the demographic variable distribution and of the annual distribution of VL epidemiological indicators. Incidence, mortality and lethality coefficients were estimated and compared annually using the G-Test. Pearson correlation coefficient analysis was employed to verify the dependence of the distribution of VL cases on rainfall and temperature throughout the period under study and the distribution of VL cases among years. The T test was used to compare the incidence of estimated cases during the rainy season and dry season. A 5\% significance level was adopted for all tests.

\section{Ethical considerations}

The project was carried out in compliance with all ethical precepts as recommended by resolution Conselho Nacional de Saúde (CNS) 466/2012, and it was approved by the Research Ethics Committee of Pontifical Catholic University of Goiás under opinion number 229.591 on March 20, 2013.

\section{RESULTS}

The study assessed 821 medical reports of patients under 15 years of age diagnosed with VL. There was no significant difference in the rate at which the genders were affected by the disease $(\mathrm{p}=0.67)$. The urban zone was the region with the highest prevalence of the disease $(99.03 \% ; \mathrm{p}<0.01)$, and the most affected ethnic group was mixed race $(85.5 \% ; \mathrm{p}<0.01)$. The distribution of the disease by age group was quite diverse; however, the most affected age group was children one to five years of age $(58.6 \% ; \mathrm{p}<0.01)$, as shown in Table 1 .

Table 2 shows that in this study, the highest incidence and mortality coefficients occurred in 2007 and 2008 (578.39/100,000 inhabitants and 18.5/100,000 inhabitants, respectively), whereas the highest lethality coefficient occurred in 2008 and 2011 (0.85/100 deaths). Figure 1 shows that the visceral leishmaniasis cases were distributed throughout all districts of the town, with a higher prevalence observed in the areas served by the Araguaína Sul Basic Public Health Unit BPHU (20.8\%) and the Nova Araguaína BPHU (15.8\%).

There was no correlation between average rainfall and number of VL cases $(r=-0.0017 ; \mathrm{p}=0.9889)$ (Figure 2A). By contrast, the correlation between temperature and the number of VL cases was negative and significant $(r=-0.4039$ and $\mathrm{p}<0.01$ ) (Figure 2B). The latter indicates that higher temperatures cause the number of recorded VL cases to decrease.

The monthly average temperature showed limited variation, and the number of VL cases recorded varied regardless of the season. The temperature varied between $25.3^{\circ} \mathrm{C}$ in the dry season and $26.3^{\circ} \mathrm{C}$ in the rainy season (Figure 3).

The distribution of VL cases related to temperature and rainfall shows that temperature was the variable that most influenced the number of VL cases $(p<0.01)$.

\section{DISCUSSION}

As shown in this study involving 821 cases, visceral leishmaniasis is a disease that can infect both genders equally. However, other studies have demonstrated a preference of the disease for male subjects ${ }^{4,5}$. This divergence in the proportion of cases by gender may be associated with local and environmental factors, as the different studies were carried out in distinct geographical regions with distinct environmental conditions $s^{4,5}$.

The phenotypic characteristics of the population of Araguaína revealed that the majority are mixed race individuals (61.6\%), which may explain the higher prevalence of the disease among these individuals ${ }^{8}$. Nevertheless, another study carried out in the northeastern region of Brazil showed the VL was most prevalent within the black race ${ }^{11}$; hence, regional features of the population may influence the prevalence of the disease, indicating that rather than being bound to a specific racial characteristic, everyone is susceptible to VL.

The high prevalence of VL in children 5 years of age and younger can be associated with several socio-economic factors: domestic and peridomestic animal breeding, health status with an emphasis on immune maturity and malnutrition studies, and children's habits that provide greater exposure to vectors ${ }^{5,9,10}$.

Visceral leishmaniasis occurs as much in urban zones as in rural areas. In Araguaína, the disease is scattered throughout the urban area with higher prevalence in the periphery and districts 
TABLE 1 - Distribution of demographic variables in children under 15 years of age in the period between 2007 and 2012 in Araguaína, State of Tocantins, Brazil.

\begin{tabular}{|c|c|c|c|}
\hline Cases & Number & Percentage & $\mathrm{P}^{*}$ \\
\hline \multicolumn{4}{|l|}{ Gender } \\
\hline male & 417 & 50.8 & 0.67 \\
\hline female & 404 & 49.2 & \\
\hline \multicolumn{4}{|c|}{ Zone of residence } \\
\hline urban & 813 & 99.03 & 0.01 \\
\hline rural & 8 & 0.97 & \\
\hline \multicolumn{4}{|l|}{ Race } \\
\hline white & 53 & 6.5 & \\
\hline black & 18 & 2.2 & \\
\hline yellow & 2 & 0.2 & 0.01 \\
\hline mixed & 702 & 85.5 & \\
\hline indigenous & 2 & 0.2 & \\
\hline ignored & 44 & 5.4 & \\
\hline \multicolumn{4}{|l|}{ Age group } \\
\hline$<1$ & 167 & 20.3 & \\
\hline $1-5$ & 481 & 58.6 & \\
\hline $6-10$ & 124 & 15.1 & 0.01 \\
\hline $11-15$ & 49 & 6.0 & \\
\hline Total & 821 & 100.0 & \\
\hline
\end{tabular}

*Chi-square test at 5\%. Source: Hospital of Tropical Diseases, Araguaína, State of Tocantins, Brazil.

TABLE 2 - Annual distribution of incidence, mortality and lethality coefficients of visceral leishmaniasis in children under 15 years of age in the period between 2007 and 2012 in Araguaína, State of Tocantins, Brazil.

\begin{tabular}{cccccc}
\hline & $\begin{array}{c}\text { Frequency } \\
\text { Year }\end{array}$ & $\begin{array}{c}\text { cumulative percent }) \\
\mathrm{p} \text {-value* }=0.08\end{array}$ & $\begin{array}{c}\text { Incidence } \\
\text { coefficient/100,000 inhabitants* } \\
\text { p-value** }<0.04\end{array}$ & $\begin{array}{c}\text { Mortality } \\
\text { coefficient/100,000 inhabitants. } \\
\text { p-value** }=0.01\end{array}$ & $\begin{array}{c}\text { Lethality } \\
\text { coefficient/100 inhabitants } \\
\text { p-value**=0.47 }\end{array}$ \\
\cline { 2 - 3 } 2007 & 193 & 23.5 & 541.6 & 16.8 & 0.73 \\
2008 & 206 & 48.1 & 546.5 & 18.5 & 0.85 \\
2009 & 118 & 62.9 & 317.1 & 2.7 & 0.12 \\
2010 & 73 & 71.9 & 168.2 & 0 & 0 \\
2011 & 129 & 87.6 & 291.9 & 15.8 & 0.85 \\
2012 & 102 & 100.0 & 226.7 & 4.4 & 0.24 \\
\hline
\end{tabular}

*Tests: Pearson correlation coefficient for annual LV case frequency. **G-test for incidence, mortality and lethality coefficients. Source: Hospital of Tropical Diseases, Araguaína, Tocantins, Brazil. 


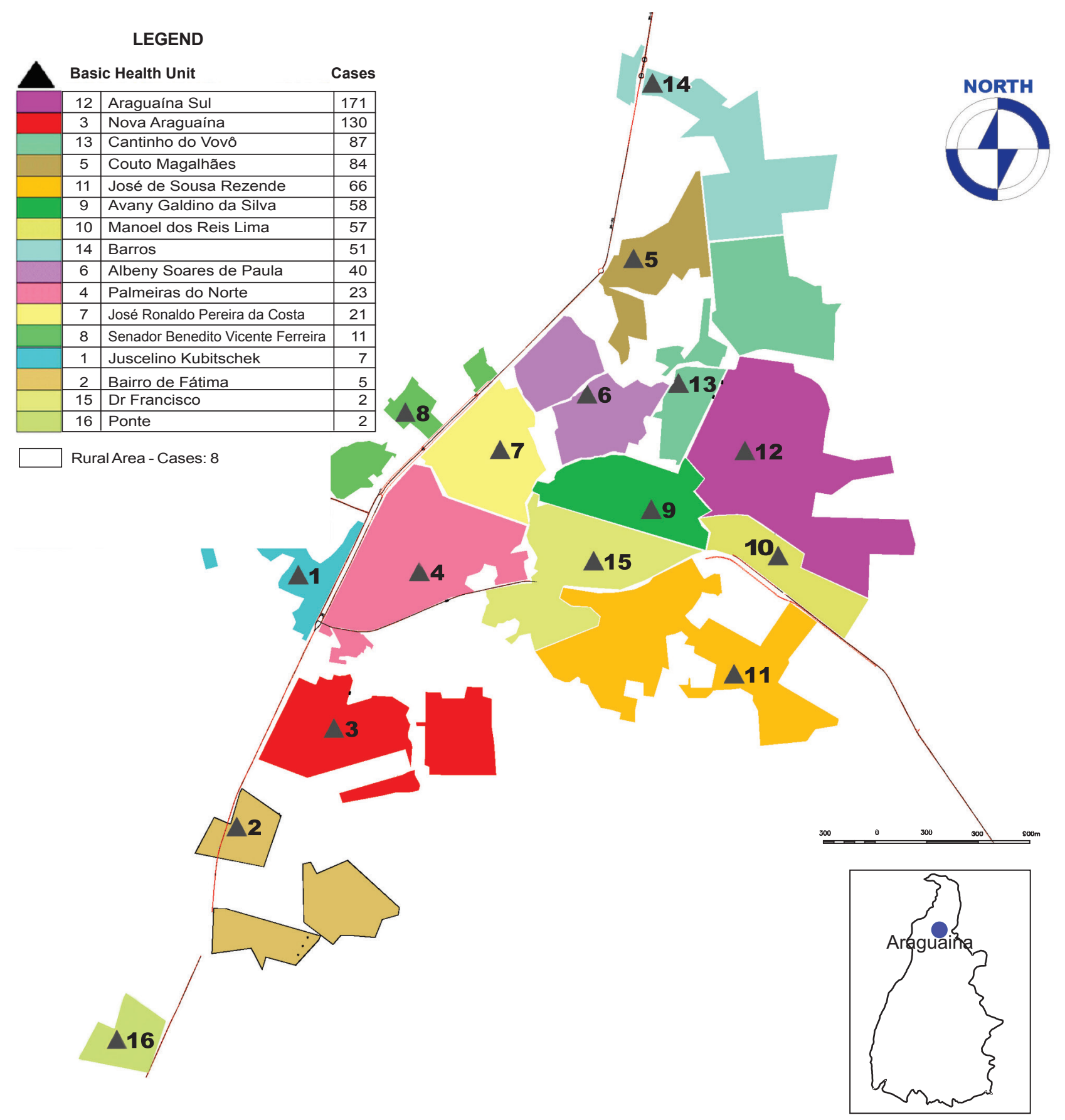

FIGURE 1 - Distribution of visceral leishmaniasis in children under 15 years of age grouped by primary healthcare unit in the period between 2007 and 2012 in Araguaína, State of Tocantins, Brazil. Source: Hospital of Tropical Diseases, Araguaína/Municipal Planning Secretariat of Araguaína, Tocantins, Brazil.

with a higher population density. The disorganized growth of the city, the increasing population density in the districts, and socioeconomic challenges such as the disorganization of the urban space, the emergence of irregular settlements and squatter areas, and the lack of basic infrastructure all may have influenced the appearance of the disease in Araguaína as a result of favorable conditions for the maintenance of the VL transmission cycle because the vectors are adapted to these conditions $^{9-11}$.

Such favorable conditions for the disease elevated Araguaína to the position of becoming a high-transmission area when compared with several other regions of Brazil ${ }^{7,12,13}$. By contrast, the decrease in the incidence coefficient in the last years of the study may be related to the development of a more effective 
(A)

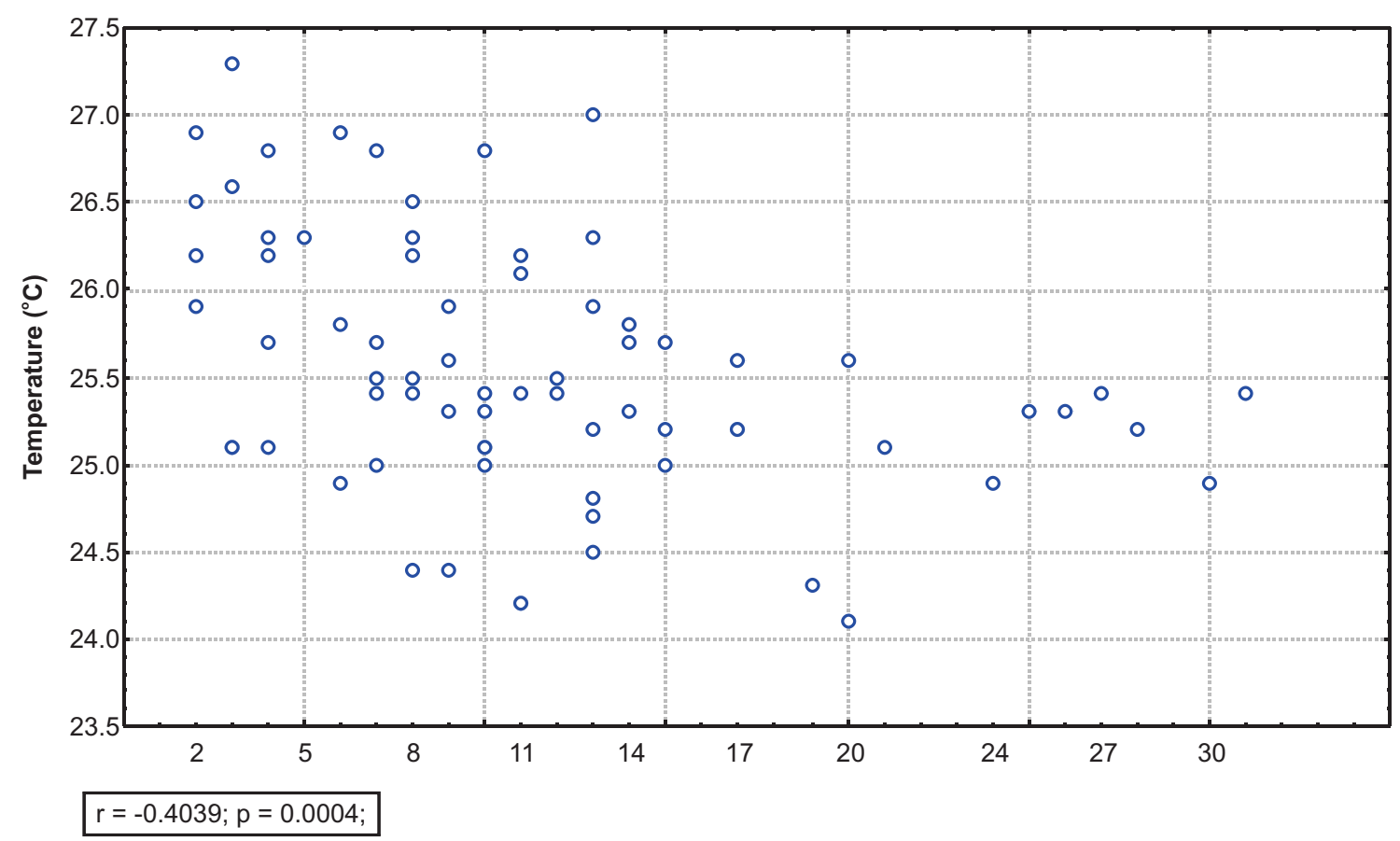

(B)

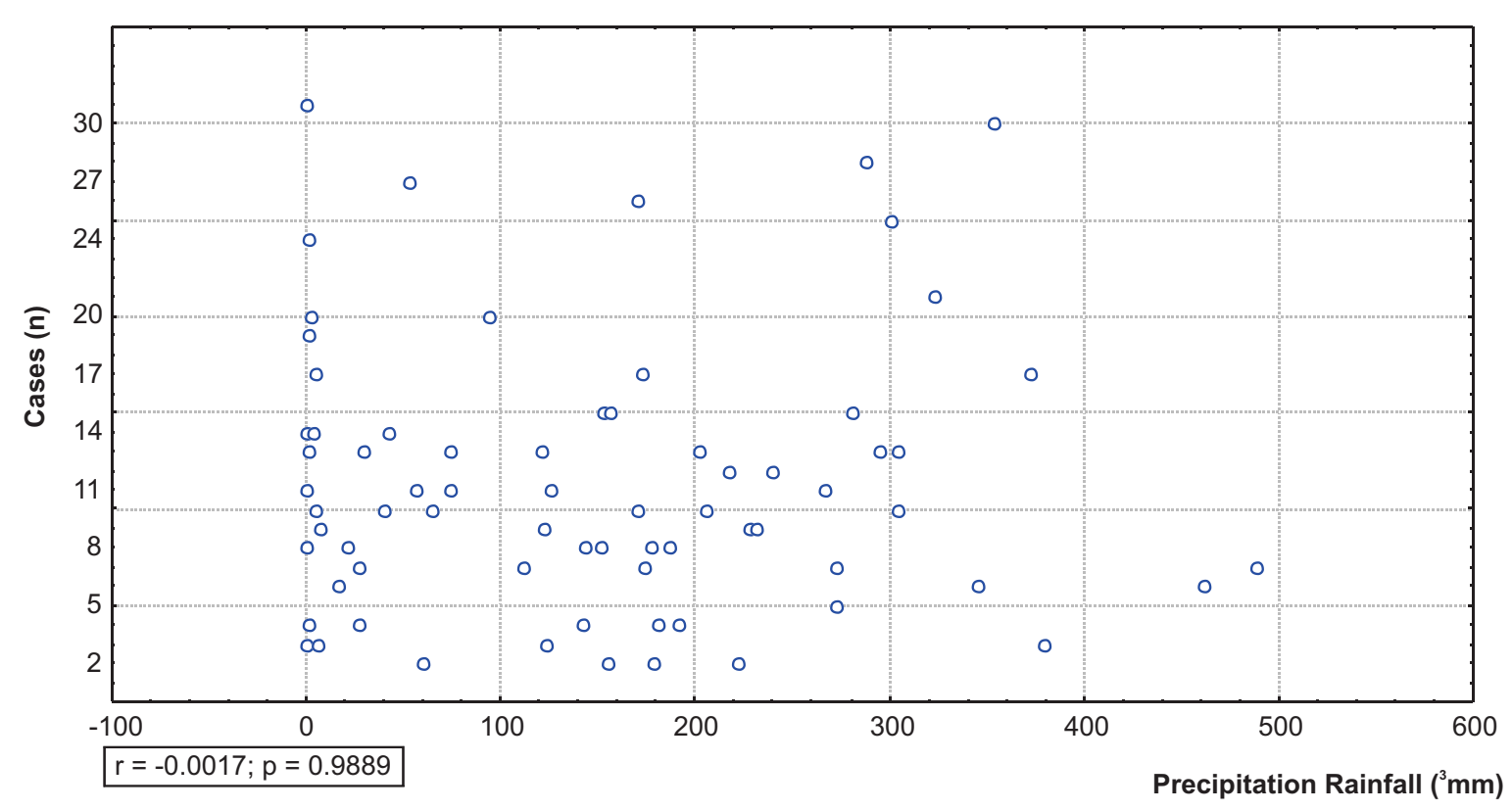

FIGURE 2A and B - Correlation between temperature, rainfall and visceral leishmaniasis cases in children under 15 years of age in the period between 2007 and 2012 in Araguaína, State of Tocantins, Brazil.

surveillance system, the clearing of vacant land, the capture of sick dogs, and improved garbage and food waste collection, all favoring the control of Lutzomyia longipalpis ${ }^{12}$.

The mortality and lethality rates for VL are higher in Araguaína than those reported in other regions of the country ${ }^{4,14,15}$. From a general perspective, the mortality rate associated with the disease is related to delays in diagnosis and medical care, being young, malnutrition, edema, bleeding, jaundice, association with comorbidities, the presence of infectious and hemorrhagic contamination, and intercurrent infections ${ }^{5,14,15}$. The nationwide challenge is to provide access to early diagnosis and adequate treatment to prevent VLrelated deaths ${ }^{4}$.

Temperature directly affected the VL incidence coefficient, suggesting that milder temperatures may increase the number of cases of the disease. The transmission of visceral leishmaniasis and the proliferation of the vector are affected by multiple factors that determine the risk of contracting the disease, 


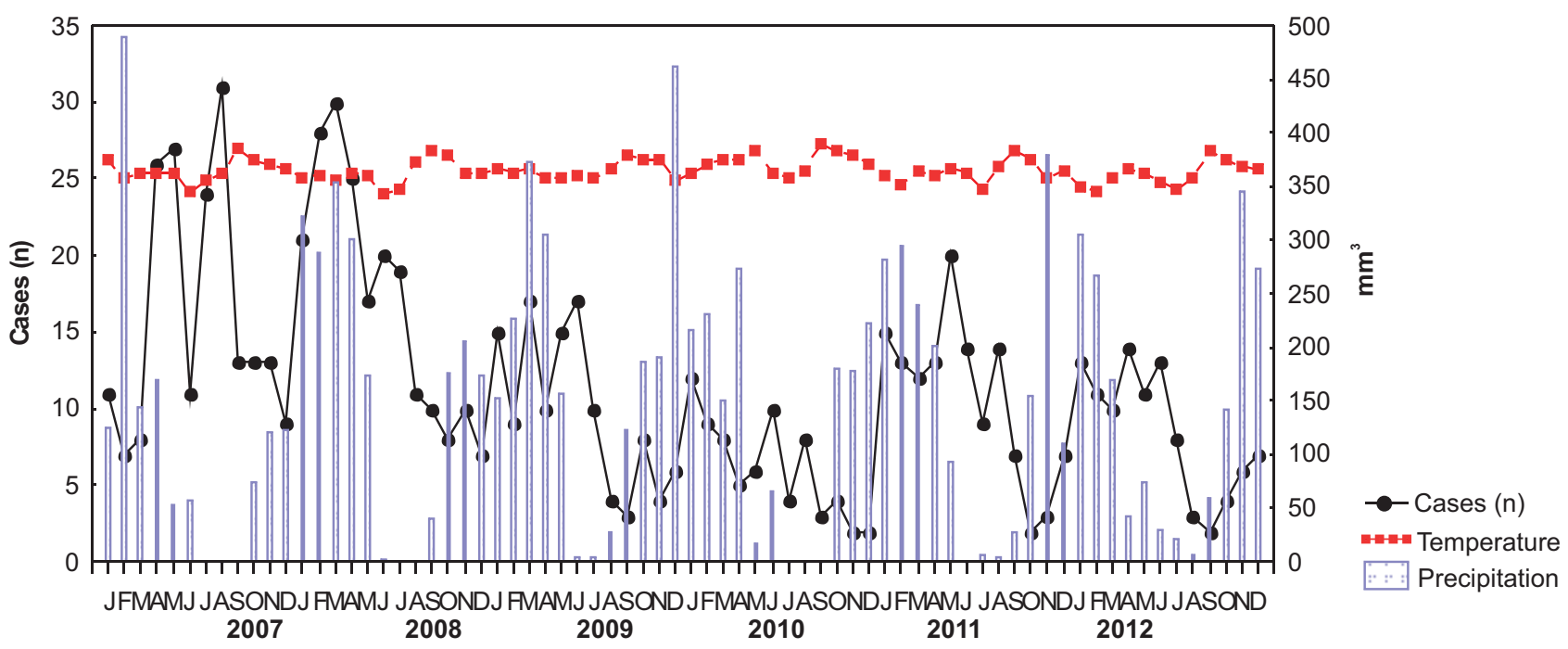

FIGURE 3 - Monthly distribution of visceral leishmaniasis cases between 2007 and 2012, frequency of cases, monthly average rainfall and monthly average temperature. J: January; F: February; M: March; A: April; M: May; J: June; J: July; A: August; S: September; O: October; N: November; D: December.

such as temperature, forestation, social conditions, organic matter accumulation, and population displacement ${ }^{16,17}$. Other studies have shown that rainfall and temperature influence (in a variable way) the population of phlebotomines, an important link in the transmission of VL, depending on the region where the research was carried out ${ }^{18,19}$.

In this study, rainfall was not a determining factor in increased reporting of the disease. However, it is known that beyond weather determinants, environmental factors in the peridomiciliary area and the presence of infected animals are fundamental components in the proliferation of the vector that facilitate the contamination process ${ }^{18-20}$. These elements cause the vector to remain in contact with the reservoir located in the peridomiciliary area, hence maintaining the transmission cycle of the disease.

Visceral leishmaniasis in Araguaína, TO, stands out as an urban-based endemic disease that preferably infects children under five years of age, showing a high incidence coefficient and thus contributing to child mortality rates in the assessed age groups. Among environmental factors, temperature was the aspect that most influenced the VL incidence coefficient.

\section{ACKNOWLEDGMENTS}

Our deepest appreciation to the research and reporting service team of the Hospital of Tropical Diseases Hospital in Araguaína, TO.

\section{CONFLICT OF INTEREST}

The authors declare that there is no conflict of interest.

\section{REFERENCES}

1. Botelho ACA, Natal D. Primeira descrição epidemiológica da leishmaniose visceral em Campo Grande, Estado de Mato Grosso do Sul. Rev Soc Bras Med Trop 2009; 42:503-508.

2. Xavier-Gomes LM, Costa WB, Prado PF, Oliveira-Campos M, Leite MTS Características clínicas e epidemiológicas da leishmaniose visceral em crianças internadas em um hospital universitário de referência no norte de Minas Gerais, Brasil. Rev Bras Epidemiol 2009; 12:549-555.

3. Borges BKA, Silva JA, Haddad JPA, Moreira EC, Magalhães DF, Ribeiro LML, et al. Avaliação do nível de conhecimento e de atitudes preventivas da população sobre a leishmaniose visceral em Belo Horizonte, Minas Gerais, Brasil. Cad Saude Publica 2008; 24:777-784.

4. Góes MAO, Melo CM, Jeraldo VLS. Série temporal da leishmaniose visceral em Aracaju, estado de Sergipe, Brasil (1999 a 2008): aspectos humanos e caninos. Rev Bras Epidemiol 2012; 15:298-307.

5. Barbosa R, Costa ICC. Aspectos clínicos e epidemiológicos da leishmaniose visceral em menores de 15 anos no estado do Rio Grande do Norte, Brasil. Scientia Medica 2013; 23:5-11.

6. Miranda GMD. Leishmaniose visceral em Pernambuco: a influência da urbanização e da desigualdade social. [Masters Dissertation]. [Recife]: Centro de Pesquisas Aggeu Magalhães, Fundação Oswaldo Cruz; 2008. $149 \mathrm{p}$.

7. Alves WA. Leishmaniasis: current situation in Brazil. Bepa 2009; 6:25-29.

8. Instituto Brasileiro de Geografia e Estatística. Cidades@:Araguaína. [Internet]. Rio de Janeiro: IBGE; 2013. Avalable at: http://cod.ibge.gov. br $/ 233 \mathrm{a} 7 /$.

9. Rangel EF, Vilela ML. Lutzomyia longipalpis (Diptera, Psychodidae, Phlebotominae) and urbanization of visceral leishmaniasis in Brazil. Cad Saúde Pública 2008; 24:2948-2952.

10. Santana JS, Silva AR, Cavalcante MNS, Silva BTF, Machado SP, Gonçalves EGR. Condições socioeconômicas, estado nutricional e consumo alimentar de crianças com Leishmaniose Visceral atendidas em serviço público de saúde da cidade de São Luis. Cad Pesquisa 2009; 16:55-62.

11. Secretaria do Planejamento e da Modernização da Gestão Pública (SEPLAN). Tocantins.[Internet]. Perfil socioeconômico dos municípios 
do estado do Tocantins: Araguaína: SEPLAN. 2013. Available at: http:// www.seplan.to.gov.br/Arquivos/download/Municipios_Perfil_2013/ Araguaina.pdf.

12. Coutinho ACC, Silva EL, Caldas AJM. Análise dos casos e óbitos por Leishmaniose Visceral no Estado do Maranhão, no período de 2000 a 2008. Rev Pesq Saude 2012; 13:11-15.

13. Braga de Lima M, Araújo R, Batista E. Epidemiologia da Leishmaniose Visceral Humana em Fortaleza-CE. Rev Bras Promoção Saúde 2009; 22:16-23.

14. Oliveira JM, Fernandes AC, Dorval MEC, Alves TP, Fernandes TD, Oshiro ET, et al. Mortalidade por leishmaniose visceral: aspectos clínicos e laboratoriais. Rev Soc Bras Med Trop 2010; 43:188-193.

15. Leite AI, Araújo LB. Leishmaniose Visceral: aspectos epidemiológicos relacionados aos óbitos em Mossoró-RN. Rev Patol Trop 2013; 42: 301-308.

16. Monteiro EM, Silva JCF, Costa RT, Costa DC, Barata RA, Paula EV, et al. Leishmaniose visceral: estudo de flebotomíneos e infecção canina em Montes Claros, Minas Gerais. Rev Soc Bras Med Trop 2005; 38 : 147-152.

17. Valderrama-Ardila C, Alexander N, Ferro C, Cadena H, Marín D, Holford TR, et al. Environmental Risk Factors for the Incidence of American Cutaneous Leishmaniasis in a Sub-Andean Zone of Colombia (Chaparral, Tolima). Am J Trop Med Hyg 2010; 82:243-250.

18. Queiroz MJA, Alves JGB, Correia JB. Leishmaniose visceral: características clínico-epidemiológicas em crianças de área endêmica. J Pediatr 2004; 80:141-146.

19. Macedo ITF, Bevilaqua CML, Morais NB, Sousa LCS, Linhares FE, Amóra SSA, et al. Sazonalidade de flebotomíneos em área endêmica de Leishmaniose Visceral no município de Sobral, Ceará, Brasil. Ciência Animal 2008; 18:67-74.

20. Viana GMC, Nascimento MDSB, Rabelo EMF, Diniz NJA, Binda Júnior JR, Galvão CS, et al. Relationship between rainfall and temperature: observations on the cases of visceral leishmaniasis in São Luis Island, State of Maranhão, Brazil. Rev Soc Bras Med Trop 2011; 44:722-724. 